\title{
RUBBERISED COIR INDUSTRY - AN INTRODUCTION
}

\author{
P. Chandy Mathew ${ }^{1}$
}

\begin{abstract}
The coconut palm is one of the versatile products of nature. Almost all parts of the tree are put to use by man. The uses of coconut kernel, shell, husk, trunk, leaves, sap etc., are well known and are therefore not described here. In this paper only one aspect of utilisation of coconut namely coconut fibre or coir for production of rubberised fibre is discussed in some detail. In major coconut producing areas more attention is given to utilisation of coconut kernel as this represents the most valuable portion of the coconut tree. It is therefore quite natural that most people concemed with coconut production and processing are less familiar with the by-products of coconut. One such by-product is rubberised coir which is a relatively capital intensive industry. In terms of "value addition" the production of rubberised coir is one of the top industries in the coconut and by-product industries. This paper is an introduction to some aspects of rubberised coir.
\end{abstract}

\section{BACKGROUND:}

The rubberised coir industry began in Europe a little after World War II. In Europe, horse hair, hog hair and animal fibres were used to produce low cost upholstery. These fibres are spun into ropes to impart a spring like structure to the fibres and they are then uncurled and bonded with natural rubber latex or synthetic resins to produce a light, low cost upholstery materials.

As there was limited availabihty of animal fibre, the process was adapted to utihse natural vegetable fibres like cpir, sisal etc. With the plentiful availability at economic prices of suitable coir fibre, it is the main fibre used in production of rubberised fibre. Rubberised coir fibre finds application of manufacture of auto-mobile seats, mattresses, cushions and industrial application like air filters, carpet underlays, bus and railway seat cushions, packaging etc. The industry enjoyed a good growth in Europe up to early 1970s. From then onwards with the advent of synthetic materials like polyurethane, the rubberised coirindustry has been decliriing. However in some countries like India, Thailand, Sri Lanka the industry has been growing steadily. There is a considerable potential and high socio-economic advantage in developIng the rubberised coir industry in relatively populous, less developed, coconut producing countries like India, Indonesia. Sri Lanka, Philippines, Thailand, Nigeria, Kenya, Brazil etc.,

\section{TECHNOLOGY}

The manufacture of rubberised coir involves the following steps :

1. Mechanical extraction of brown coir fibre from mature coconut husks.

2. Curling of brown coir fibres into curled or twisted coir rope

3. Processing of curled rope into rubberised coir pads on automatic machines by bonding with latex (Natural rubber or synthetic) and moulding or pressing to required shapes.

4. Conversion of rubberised coir pads into marketable forms like mattresses, automobile seat cushions etc., and marketing these products.

\footnotetext{
${ }^{1}$ Director, Duroflex Coir Industries, Private Limited, Bangalore, India.
} 
The machinery for mechanical extraction of coir fibre are freely available in various coir producing countries. Until recently the machinery for manufacture of curled rope and rubberised coir were available only from Europe. The European machinery are generally highly regarded for their excellent performance, sturdiness and reliability. However, with the erosion in value of currencies of most developing countries the price of European machinery is less cost effective for developing countries.

Currently some developing countries like India, have also developed machine building capability for production of curled coir and rubberised coir machinery which is reasonably cost effective. The manufacturing process of rubberised coir is illustrated in Figure 1.

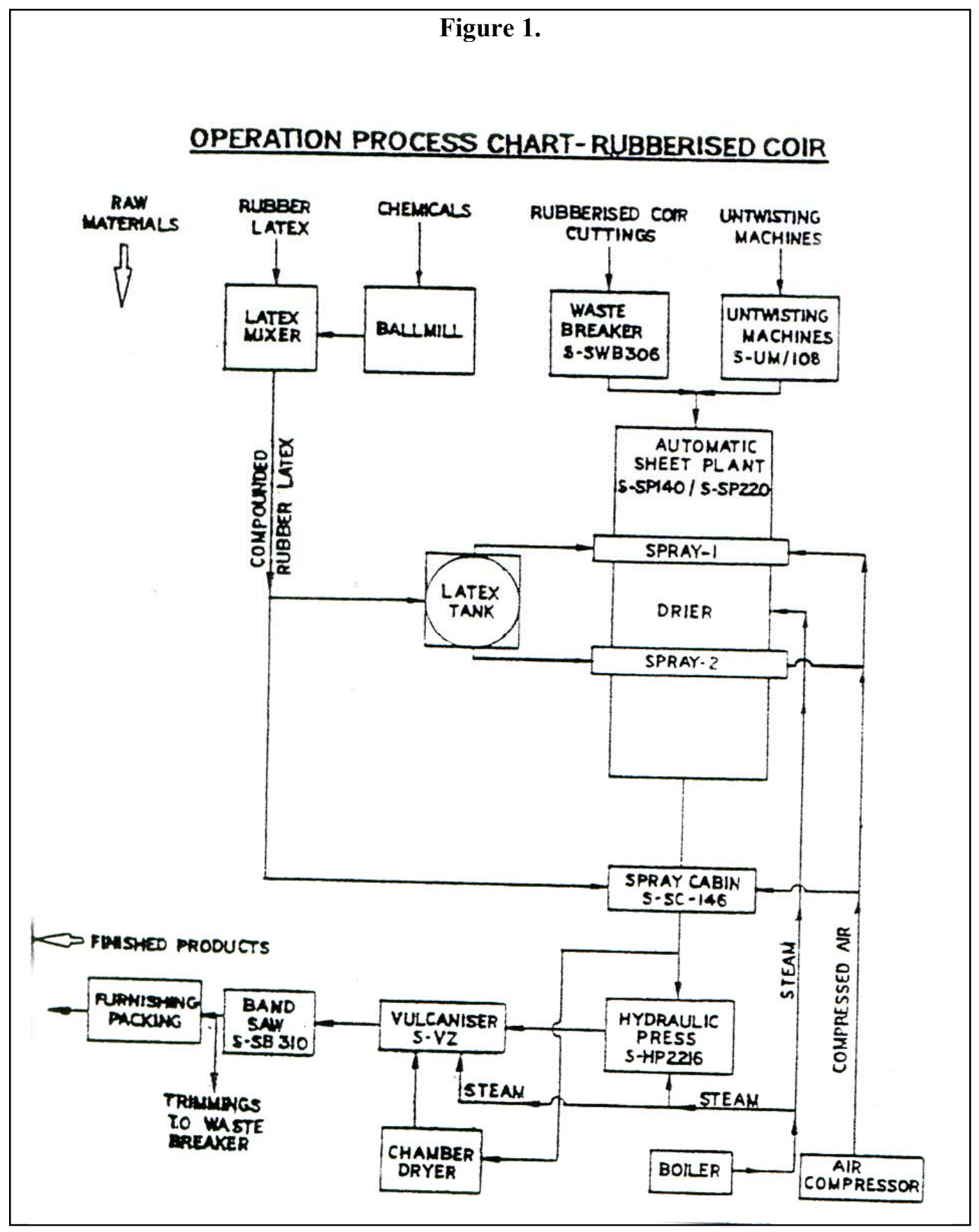




\section{EMPLOYMENT}

The rubberised coirindustry,is relatively capital intensive and less labour intensive industry especially as compared with traditional coir industry manufacturing coir yarn mats and mattings. However it is still more labour intensive than polyurethane foam industries. Moreover there is significant employment generation in up stream coir. production and curling as well as rubber production as well as in down stream marketing operations.

The employment potential of the industry is illustrated below:

(a) Froduction of brown fibre 1,000 T/annum requires about 200 people

(b) Production of curled coir fibre about 1,000 T/annum required about 90 people

(c) Production of marketing of rubberised coir of 1,000 T/annum requires about 150 people

From the above it can be seen that about $1000 \mathrm{~T}$ will generate additional employment for about 440 people directly in the fibre sector alone. In addition to this employment will be also generated in processing of rubber latex procurement and transportation of husks, marketing and other down stream operations.

Some interesting data (approximate for 1986) for India are given below as this may have relevance in other countries wishing to develop brown fibre production and rubberised coir industry. It is relevant to state that in India the production of brown coir fibre is about $60,000 \mathrm{~T} / \mathrm{annum}$ and the production of curled coir fibre is about 7,000T/annum. The production of rubberized coir is about $8,000 \mathrm{~T} / \mathrm{annum}$.

The total employment directly and indirectly in production of brown fibre, curled fibre and rubberised coir is approximately 15,000 people. Here it is worthwhile to note that out of total brown fibre production of $60,000 /$ only about 7,000T is used for curled rope the main raw material for rubberised coir and the remainder finds other uses such as rope making and cheap uphol stery stuffmg etc. However the development and growth of rubberised coir has played an important role in providing an organised and standard outlet for the coir fibre and therefore in the development of brown coir fibre.

\section{VALUE ADDITION IN RAW MATERIALS:}

Before the development of brown fibre industry and rubberised coir industries in India dried coconut husks were used for cheap fuel. With expansion of coconut production and more availability of husks the utilisation of coconut husks for brown fibre, curled rope and rubberised coir have generated extra income to small coconut growers, agricultural labourers and industrial workers in small fibre extraction and curling units in rural areas.

The accrual of extra income from hitherto waste materials is approxim ately as. follows :

(a) From coconut husks to produce $60,000 \mathrm{~T}$ of brown fibre approximately Rs.90 million (US\$7 Million)

(b) Sales value of $60,000 \mathrm{~T}$ of brown fibre @ Rs.2,000T Rs.120 million. Therefore the value addition in fibre extraction approximately Rs. 30 million (US\$,21.3 Million)

(c) Value addition in producing 7,000T curled rope Ca, Rs.2,500/ above brown fibre price Rs.17.5 million approximately US\$1.4 million. 
(d) Value addition of rubberised coir 8,000T of 30,000/T is Rs.240 million approximately US\$18.5 million

From the above some idea of the income generation and value addition at each stage can be obtained. The above figures are quite significant in rural agricultural economies with low income levels.

\section{MARKET CONSIDERATIONS IN INVESTMENT IN RUBBERISED COIR}

As stated earlier the rubberized coir industry is more capital intensive than traditional coir industries. The estimated cost of a project producing 1000T/annum will involve a total investment $6 \mathrm{f}$ approximately US\$ 1.5 million in fibre extraction, curling and rubberized coir manufacturing. Assuming that the main product from this factory will be mattresses for the domestic market this will mean a production of about 100,000 mattresses per annum. This is no doubt a large figure for most countries. But if these figures can be achieved in 3-5 years of commencement of production, then there is a case for setting up a viable rubberised coir industry. follows :

However the necessary conditions to be satisfied before considering investment are as

(a) Availability of domestic market of at least 15,000 mattresses per annum to start with

(b) Preference in goverrunent purchases

(c) Marketing and advertising support.

(d) Entrepreneurial, skills of promoters

(e) Active goverrunent support

\section{GOVERNMENT SUPPORT}

In coconut growing countries such as Indonesia, Philippines, Sri Lanka, Malaysia. India, Nigeria, Brazil etc., natural rubber is also nonnally cultivated. Therefore all the main raw materials required for rubberised coir production namely coir fibre natural rubber can be locally available and there is no need to import them. Considering this aspect, the value added in rural sector and employment potential it makes strong economic sense for governments to help promotion of rubberised coir units in countries which grow coconut and rubber.

The main competition for cushioning is from synthetic polyurethane foam the raw materials for which have to be imported into all developing countries. The polyurethane raw materials are produced in developed countries by large multi-nationals. To encourage the growth of rubberised coir industry governments have to consider the following:

(a) Import duties on chemicals for polyurethane manufacture

(b) Excise duties/taxes on synthetic foams

(c) Subsidy for rubberised coir manufacture

(d) Government support in purchases of hospitals/buses/railways

(e) Concessional finance and investment subsidies

(f) Making available suitable land and building

(g) A combination of the above. 


\section{MARKET \& PRODUCT POSSIBILITIES}

The product possible from a rubberised coir factory are

(a) Mattress - medium/low priced mattresses for domestic use

(b) Automobile/Bus/Railway - seat cushions and back rests

(c) Air - filters

(d) Idustrial Packaging

(e) Needled Felt - for stuffing, geo textiles, industrial applications.

In hot and humid climates rubberised coir is an ideal mattress material as it offers the following advaniages

(a) Low cost

(b) Porous construction allows body heat dissipation and therefore the mattress and body will not get as hot

(c) It does not absorb liquids, so is ideal for use in hospitals

(d) Rubberised coir is firm and offers good back support

In India, after many years of marketing effort, the rubberised coir mattresses have now become popular and are preferred over synthetic polyurethane and natural rubber foam due to the above advantages. It is estimated that over $80 \%$ of the industry production is marketed as mattresses.

The viability of new rubberised coir industry must tberefore depend on the availability of a reasonably sized mattress market.

\section{INVESTMENT}

The investment requirements in a rubberised coir unit are outlined below:

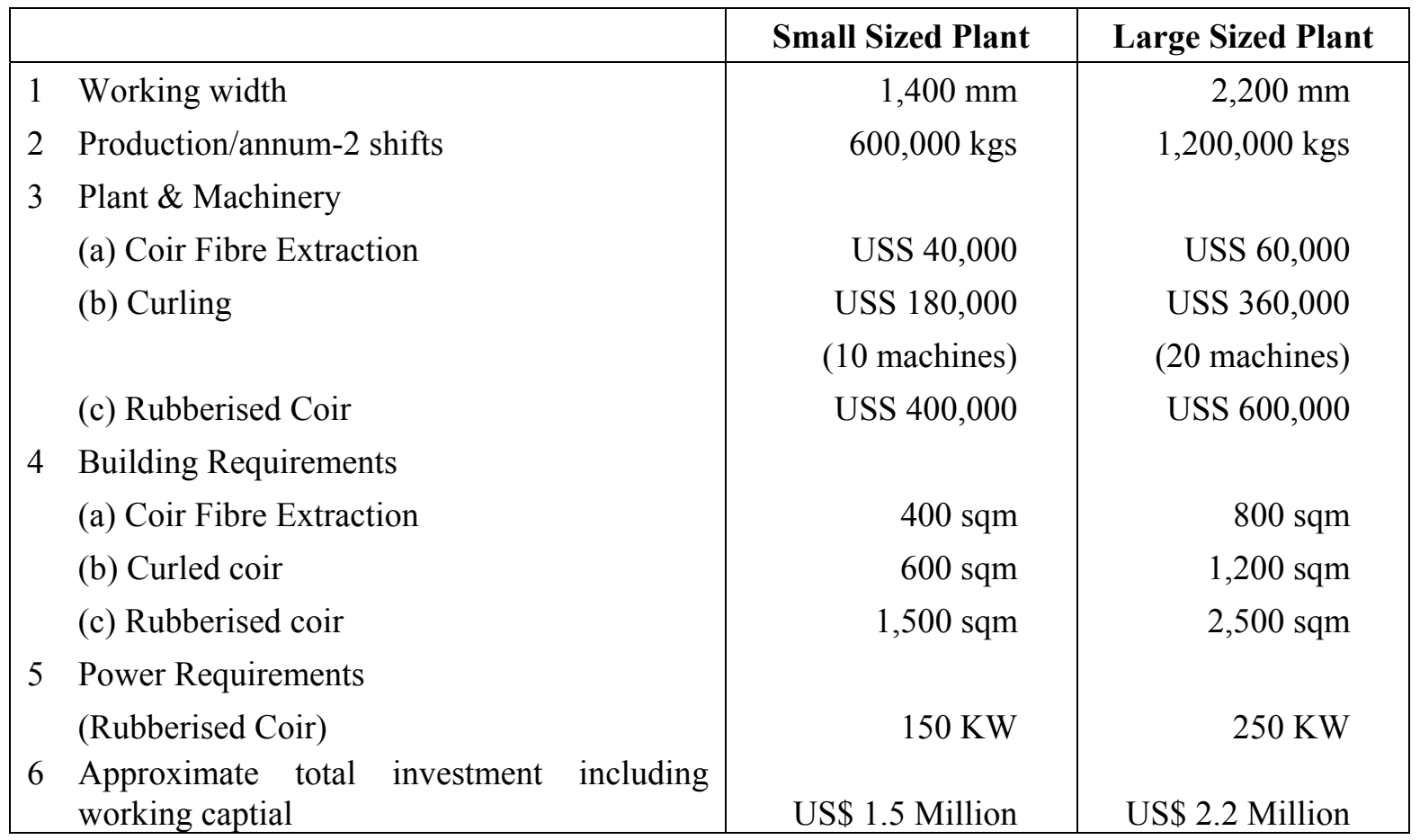




\section{SUMMARY \& CONCLUSIONS}

The rubberised coir industry offers considerable socio-economic advantage to coconut producing countries. The rubberised coir industry should be of interest to those countries that have coconut as well as rubber cultivation. The availability of a reasonable sized mattress market is necessaxy for setting up a viable industry as well as active goverment support. 